\title{
Dvadeset godina studija povijesti u Puli (1994. - 2014.)
}

\author{
Pregledni rad \\ Review article \\ UDK 378.694(497.5 Pula),,1994/2014“
}

\begin{abstract}
Članak je napisan prigodom obilježavanja dva desetljeća rada Odsjeka za povijest na Sveučilištu Jurja Dobrile u Puli i predstavlja dokumentirani korpus podataka o osnivanju, razvoju i postupnom okupljanju vanjskih i stalnih suradnika. Iz temelja učiteljske škole, koji su postavljeni u prvim poratnim godinama, postupno su stečeni uvjeti da se 1994. otvori jednopredmetni i dvopredmetni preddiplomski i diplomski studij povijesti. Osnovne karakteristike studija jesu izbornost i interdisciplinarnost. Studenti obveznim predmetima usvajaju temeljna znanja iz svjetske i hrvatske povijesti, ali u znatnoj mjeri samostalno oblikuju svoj studij putem izbornih modula i predmeta. Uz pomoć kolega profesora s drugih hrvatskih sveučilišta i znanstvenih ustanova te samo nekoliko stalno zaposlenih djelatnika, nastavnički se kadar sve više osposobljavao pa danas Odsjek broji 15 djelatnika koji izvršavaju obaveze vezane uz nastavu kao i u okviru pojedinačnog znanstvenog interesa. Rad nastavnika na Odsjeku danas je organiziran u dvije katedre, Katedru za staru i srednjovjekovnu povijest i Katedru za novovjekovnu i suvremenu povijest. Nastavnici su angažirani na mnogim poljima unutar Sveučilišta kao i u široj društvenoj zajednici. U daljnjem razvoju naglašeno je pozicioniranje Odsjeka kao centra izvrsnosti i modernog promišljanja aktivnosti kroz organizaciju kongresa, pokretanje Jadranske medijevističke škole, osnivanja centra za interdisciplinarna arheološka istraživanja te pokretanja doktorskog studija.
\end{abstract}

Ključne riječi: studij povijesti, Sveučilište Jurja Dobrile u Puli, Odjel za humanističke znanosti, Odsjek za povijest

$\mathrm{O}^{\mathrm{s}}$ dsjek za povijest i studij povijesti doživjeli su postepen razvojni put u okvirima više pedagoško-odgojno-znanstvenih ustanova. Odsjek za povijest danas je ravnopravna sastavnica Odjela za humanističke znanosti Sveučilišta Jurja Dobrile u Puli. Smješten je u secesijskoj zgradi ${ }^{1}$ koja je izgrađena $1907 .^{2}$ za potrebe tadašnjeg Ženskog liceja. U posljednjih

B. Nefat, http://istra.Izmk.hr/clanak.aspx?id=2665, 27. siječnja 2014.

U izvorima i literaturi navode se različiti datumi:

Giornaletto di Pola: škola je otvorena 5. studenog 1902. (Pola, 29 Ottobre: Il giorno 5 novembre a. c. avrà luogo l'apertura del Liceo Provinciale Femminile di Pola, che nell'anno scolastico 1902-3 funzionerà col I corso; Pola, 14 Novembre 1902: il Podestà quindi comunica: che il Liceo Femminile Provinciale fu aperto il 5 corr. coll'intervento del Capitano Provinciale.

Bernardo Benussi navodi da je 5. studenog 1902. otvoren Liceo Provinciale Femminile per allora in una 
stotinu godina povijesne mijene ostavile su duboki trag u graditeljstvu, ali i u demografskoj slici Pule. Istrom su prohujala dva svjetska rata, a zgrada je uvijek bila u funkciji odgoja i obrazovanja.

Stvaranje obrazovnog kadra u Istri ima korijene u osnivanju, odmah po završetku Drugog svjetskog rata, 1945., Učiteljske škole „Viktor Car Emin“. S obzirom na to da je Pula tada bila pod angloameričkom okupacijom, škola je započela s radom u Opatiji. Otvaranje stručne škole s petogodišnjim trajanjem školovanja imalo je povijesni značaj za Istru zbog osposobljavanja učiteljskog kadra. Učitelji prve generacije školske godine 1949./50. bili su kamen temeljac pedagoškoj struci u Istri. Ustanova je nastojala prepoznati i zadovoljiti kadrovske potrebe odgojno-obrazovnih ustanova u Istri. Nekoliko godina kasnije, nakon odlaska okupacijskih snaga i priključenja Istre Hrvatskoj, škola je 15. veljače 1948. preseljena u Pulu. ${ }^{3} \mathrm{U}$ tim okvirima možemo tražiti početak visokoškolskog obrazovanja nastavnika. Naime, 1961. utemeljena je Pedagoška akademija. ${ }^{4}$ Studij je bio usmjeren u više dvopredmetnih kombinacija, koje su obuhvaćale predmete: hrvatski ili srpski jezik, povijest, zemljopis, biologiju, kemiju, matematiku, fiziku, tehničko obrazovanje te razrednu nastavu. Na studiju povijesti predavali su Miroslav Bertoša i Branimir Šebelić. ${ }^{5}$ U sklopu Akademije kao zasebna

sede provvisoria, no da je već 4 . veljače 1904. Gradsko zastupništvo donijelo odluku o izgradnji nove zgrade škole, za što je bilo namijenjeno 320.000 kruna (Benussi 1923: 152).

Zgrada je izgrađena 1905. godine kao ženski licej. Izvor: virtualna zavičajna zbirka Gradske knjižnice Pula (http://www.skyscrapercity.com/showthread.php?t=1015367\&page=53), 27. siječnja 2014.

„CRTICE IZ PROŠLOSTI“ - Mädchen Lyzeum. Liceo Provinciale. Pokrajinski licej. Početkom 1907. godine svečano otvoren ženski licej u današnjoj Pedagoškoj akademiji (http://www.pula-online.com/article. php?id=2590), 21. ožujka 2014.

Secesijska zgrada u ulici Ivana Matetića Ronjgova izgrađena 1907. godine kao Pokrajinski ženski licej na talijanskom jeziku prema projektu arhitekta Rodolfa Borrija. - podaci na razglednici koja je odaslana iz Pule 3. kolovoza 1907. godine u Petrovaradin, Srijem (Novi Sad, Srbija). (1907. ?) Izdavač: M. Schulz. Gradska knjižnica i čitaonica Pula - Zavičajna zbirka; G-R13.

http://vizz.gkc-pula.hr/hr/gradja/eksponat/24/

Zgrada je izgrađena 1907. - M. Bogneri, Cronache di Pola e dell'Istria: 1847-1914, Trieste: Unione degli Istriani, s.a. <ca. 1989.>, str. 194. Autor ne navodi izvor, ali iz popisa korištenih novina može se zaključiti da je to Giornaletto di Pola.

Ženski licej, sjajno secesijsko zdanje usred parka, djelo inženjera arhitekta Rodolfa Borrija dovršeno 1907..., (Krizmanić 2005: 159).

Iz jednog nepotpisanog i nedatiranog dopisa iz Pismohrane o značaju, povijesti, razvoju i stanju Pedagoškog fakulteta doznajemo: „Zgrada Pedagoškog fakulteta nalazi se u Medulinskoj ulici br. 3, preko puta palače MUP-a, a u blizini velike Robne kuće i gradske tržnice. Izgrađena je u stilu secesije, a nalazi se usred parka sa fontanom okružena elegantnom ogradom izrađenom od željeza. Objekt je dug 60 metara, a podignut je na dva kata. Interijer i eksterijer čine jedinstvenu arhitektonsku ljepotu u ovom dijelu Hrvatske. Kamen temeljac postavljen je 1904. U tom kamenu je probušena rupa u koju je stavljen stakleni cilindar sa tekstom: /l aprile 1904 u prisustvu gradskih i vojnih vlasti pokrajine Istre dr. Lodovico Rizzi na području situiranom iznad ulice Campo Marzio (Medulinske) i San Michele bio je ovog dana postavljen kamen temeljac po ing. Arhitekture Rodolfa Barri-ja za novi pokrajinski ženski licej Arra Palladio za moralnu regeneraciju, intelektualnu i civilnu grada i pokrajine. Licej je bio izgrađen 23. lipnja 1919. i predan na upotrebu.“

Ovom prilikom zahvaljujem svim kolegama na pomoći u rasvjetljavanju godine izgradnje zgrade u kojoj djeluje Odsjek za povijest Odjela za humanističke znanosti Sveučilišta Jurja Dobrile u Puli. Moje zahvale idu prof. dr. sc. Darku Dukovskom, Nataši Nefat i ponajprije dr. sc. Brunu Dobriću, koji je iz većeg broja izvora pohranjenih u Sveučilišnoj knjižnici u Puli detektirao najtočnije podatke.

3 Škola će nositi ime Viktora Cara Emina do ak. godine 1964./65. (Dopis mr. sc. Mate Križmana, pročelnika Ureda za prosvjetu, kulturu, informiranje, šport i tehničku kulturu, KLASA: 602-01/00-01/70, URBROJ: 2163-04-00-1 od 29. veljače 2000.).

$4 \quad$ Zbog poboljšanja društvenih uvjeta provedena je reforma nastavničkog kadra, gdje su nastavnici osnovnih škola morali imati višu stručnu spremu. Pedagoška akademija osnovana je rješenjem NO Kotara Pula: broj: S-69/11961 od 20. ožujka 1961., a prvih 125 redovitih studenata, upisali su prvu akademsku godinu 1961/1962. Prvi direktor bio je Tone Peruško (Petrić 1986: 9).

5 Posljednja generacija studenata studijske grupe zemljopis - povijest upisana je 1966/1967. (Petrić 1986: 10). 
cjelina djelovao je Talijanski odsjek, dok je studij glazbenog odgoja počeo s radom 1965., a 1967. studij razredne nastave postao je jednopredmetnim. Otvaranjem studija predškolskog odgoja 1975. zaokruženo je visokoškolsko obrazovanje za pedagoške potrebe. ${ }^{6}$

Godine 1978., Pedagoška akademija postala je dijelom Pedagoškog fakulteta u Rijeci. ${ }^{7}$ U Puli tada djeluju dva dvogodišnja studija (razredna nastava, predškolski odgoj) i dva četverogodišnja studija (talijanski jezik i književnost, glazbena kultura). Ispunjavanjem uvjeta za izvođenje znanstveno-nastavne djelatnosti ${ }^{\circ}$, od akademske godine 1978/1979. OOUR Nastavne djelatnosti Pula postoji kao visokoškolska ustanova, odnosno fakultet. Iz vrlo složene situacije pulska se nastavnička ustanova postepeno transformirala u visoku školu (Petrić 1986: 14).

Početkom 1990-ih ${ }^{9}$ počelo se raditi na otvaranju novih studija pa su 1994 . otvorena još tri studija u dvopredmetnim kombinacijama: hrvatski jezik i književnost, talijanski jezik i književnost, povijest, dok je 1999. pokrenut studij latinskoga jezika i rimske književnosti. Opravdanost otvaranja studija povijesti obrazložena je nedostatkom kadra u mnogobrojnim osnovnim i srednjim školama, kao i kulturnim te znanstvenim ustanovama Istre (Povijesni muzej Istre ${ }^{10}$, Povijesni arhiv u Pazinu ${ }^{11}$, Centro di ricerche storiche - Rovigno - Centar za

http://istrapedia.hr/hrv/1348/visoka-uciteljska-skola-u-puli/istra-a-z/, 27. siječnja 2014.

Ustanova vremenom mijenja ime, a došlo je i do promjene naziva ulice sjedišta.

OOUR Pedagoška akademija Pula, Medulinska 3 (1-990-03) upisana je u sudski registar temeljem rješenja o konstituiranju nove radne organizacije pod posl. br. Fi-859/77, od 1. ožujka 1978., kao Sveučilište u Rijeci Pedagoški fakultet, o.o. Rijeka, OOUR Pedagoška akademija Pula.

Rješenjem posl. Br. Fi-298/79. od 21. svibnja 1979., u sudski registar proveden je upis promjene naziva OOUR-a „Pedagoška akademija Pula“, tako da on glasi: Sveučilište u Rijeci - Pedagoški fakultet Rijeka - osnovna organizacija Nastavne djelatnosti Pula, Medulinska 3, u reg. ul. br. 1-990-03.

Rješenjem posl. br. Fi-747/87. od 22. listopada 1987. u sudski registar proveden je upis promjene naziva OOUR-a „Nastavne djelatnosti“ Pula, tako da novi naziv glasi: Sveučilište „Vladimira Bakarića“ u Rijeci, Pedagoški fakultet, o.o. Rijeka - OOUR „Znanstveno-nastavne djelatnosti Pula“ sa sjedištem u Puli, Medulinska 3, u reg. ul. br. 1-990-03.

Rješenjem posl. br. Fi-2131/91. od 14. svibnja 1991. u sudski registar proveden je upis osnivanja Sveučilišta u Rijeci - Pedagoški fakultet u Puli, sa sjedištem u Puli, Medulinska 3, u reg. ul. br. 1-2801-00.

Rješenjem posl. br. Fi-3387/94. od 9. svibnja 1994. u sudski registar proveden je upis brisanja iz reg. ul. br. 1-2801-00, radi upisa u registar ustanova - ustanove Sveučilište u Rijeci, Pedagoški fakultet u Puli, Medulinska 3, tako da je ustanova upisana u reg. ul. br. U-1-198-00.

Rješenjem posl. br. Tt-96/410-2. od 31. srpnja 1996. u sudski registar proveden je upis usklađenja ustanove sa Zakonom o visokim učilištima (N.N. br. 96/93), tako da je upisana pod nazivom: Republika Hrvatska, Sveučilište u Rijeci, PEDAGOŠKI FAKULTET U PULI, sa sjedištem u Puli, Medulinska 3.

Rješenjem posl. br. Tt-98/2129-2 od 25. studenoga 1998. u sudski registar proveden je upis promjene sjedišta ustanove, tako da je upisano: Pula, I. Matetića Ronjgova 1.

Rješenjem posl. br. Tt-99/1031-2 od 20. svibnja 1999. u sudski registar proveden je upis promjene sjedišta, odredbi Statuta i tvrtke, tako da je subjekt upisan pod nazivom: Sveučilište u Rijeci - Filozofski fakultet u Puli, sa sjedištem u Puli, Matetića Ronjgova 1.

Rješenjem posl. br. Tt-00/1544-2. od 17. srpnja 2000. u sudski registar proveden je upis promjene, tako da se ustanova koristi u pravnom prometu dvojezičnom nazivom: Sveučilište u Rijeci - Filozofski fakultet u Puli, sa sjedištem u Puli, Matetića Ronjgova 1, odnosno: Università di Fiume - Facoltà di Lettere e Filosofia di Pola.

(Svi podaci iz: Potvrda Trgovačkog suda u Rijeci, Sudski registar, Klasa: 602-04/05-01/92, Urbroj: 2168-380/0501/04, od 12. travnja 2005.)

8 Po Zakonu o visokom školstvu ustanova je morala imati najmanje 15 znanstvenika sa znanstveno-nastavnim zvanjem od kojih najmanje pet s doktoratom znanosti zaposlenih u stalnom radnom odnosu (Petrić 1986: 14).

9 Zahtjev da se Pedagoškom fakultetu omogući otvaranje studija hrvatskog jezika, povijesti, talijanskog i njemačkog jezika kao dvopredmetni studij upućen je Ministarstvu za prosvjetu, kulturu i šport 26. lipnja 1992.

10 Od 2000. - 2011. Povijesni muzej Istre - Museo storico dell' Istria; od 2011. - Povijesni i pomorski muzej Istre - Museo storico e navale dell'Istria (http://www.istrapedia.hr/hrv/705/povijesni-muzej-istre/istra-a-z/, 19. ožujka 2014.)

11 Od 1993. - 1997. Povijesni arhiv Pazinu; od 1997. - Državni arhiv u Pazinu (http://arhinet.arhiv.hr/details. aspx?|temld=3_3165, 19. ožujka 2014.) 
povijesna istraživanja - Rovinj - Središče za zgodovinska raziskovanja - Rovinj, Arheološki muzej Istre u Puli, Etnografski muzej u Pazinu, Sjevernojadranski institut HAZU ${ }^{12}$ ). Nedovoljno obrađene i osvijetljene povijesne teme od samih početaka do suvremenosti dodatni su razlog želje da se u Puli osposobljavaju studenti za istraživanje povijesti suvremenim metodama u cilju objektivnog promišljanja prošlosti. Nadalje, položaj Istre na karti Europe u zemljopisnom, ali i povijesnom smislu, te mnogobrojna arheološka, arhivska građa, bili su poticaj za pokretanje studija povijesti u Puli.

Dana 24. svibnja 1995. na sjednici Fakultetskog vijeća Pedagoškog fakulteta u Puli kao treća točka dnevnog reda bila je dopuna ustroja fakulteta. Nakon rasprave Fakultetsko vijeće donijelo je odluku o ustrojbenim jedinicama. Od tada, u sastavu Fakulteta djelovale su i izvodila se nastava za pojedine studije, odsjeke, odnosno katedre:

1. ODSJEK ZA POVIJEST, čijim je predstojnikom imenovan dr. sc. Miroslav Bertoša, redoviti profesor, a njegovim zamjenikom imenovan je dr. sc. Robert Matijašić.

2. ODSJEK ZA KROATISTIKU

3. ODSJEK ZA TALIJANSKI JEZIK I KNJIŽEVNOST

4. GLAZBENI ODSJEK

5. TALIJANSKI ODSJEK

6. ODSJEK ZA RAZREDNU NASTAVU I PREDŠKOLSKI ODGOJ

7. USTROJBENA JEDINICA ZA ZAJEDNIČKE PREDMETE ${ }^{13}$

Prof. dr. sc. Miroslav Bertoša bio je predstojnik Odsjeka za povijest od ak. god. 1994/1995. do 2001/2002. te od 2006/2007. do 2007/2008. Od 2002/2003. do 2005/2006. te 2008/2009. tu će funkciju preuzeti prof. dr. sc. Slaven Bertoša. Prof. dr. sc. Klara BuršićMatijašić obavljala je dužnost predstojnice u dva mandata, od ak. god. 2009/2010. do 2012/2013. ${ }^{14}$ Danas Odsjek vodi doc. dr. sc. Igor Duda.

Četverogodišnji dodiplomski studij povijesti, tada treći u zemlji uz zagrebački i zadarski, osmislio je prof. dr. sc. Miroslav Bertoša u suradnji s prof. dr. sc. Slavenom Bertošom, prof. dr. sc. Robertom Matijašićem i prof. dr. sc. Darkom Dukovskim, a izvodio se punih deset godina. Prve godine upisano je 26 studenata od kojih je njih 21 uspješno završilo studij. Posljednja je generacija u program dodiplomskoga dvopredmetnoga studija upisana akademske godine 2004/05.

Od samih početaka nastava nije mogla biti organizirana bez pomoći profesora s drugih sveučilišta, ponajprije Zagreba i Zadra. Nastavni plan i program bio je koncipiran kronološkim redom, a dopusnice Nacionalnog vijeća za visoko obrazovanje tražile su se i dobivale iz godine u godinu. Prvih godina u nastavi su bili angažirani akademik Petar Strčić, akademik Tomislav Raukar, prof. dr. sc. Šime Batović, prof. dr. sc. Neven Budak, prof. dr. sc. Ivo Goldstein, prof. dr. sc. Borislav Grgin, prof. dr. sc. Zdenka Janeković Römer i prof. dr. sc. Drago Roksandić. Na prvoj su godini tada vanjski suradnici bili prof. dr. sc. Robert Matijašić i prof. dr. sc. Klara Buršić-Matijašić, koji će biti stalno zaposleni 1996., odnosno 2001. Prof. dr. sc. Slaven Bertoša zasniva stalni radni odnos od ožujka 1995., prof. dr. sc. Robert Matijašić 15. lipnja 1996., dok izv. prof. dr. sc. Ivan Jurković stalno zaposlenje dobiva 15. rujna 1997. Akademske godine 1998/1999. nastavu održavaju vanjski suradnici prof. dr. sc. Stijepo Obad, prof. dr. sc. Darko Dukovski, dr. sc. Ivica Prlender i prof. dr. sc. Borislav Grgin, kao i prof. dr. sc. Nevio Šetić, koji je zaposlen na Sveučilištu 2011. godine. Održavanje nastave metodike bilo je 1998/1999. povjereno dr. sc. Stipanu Trogrliću. Prof. dr. sc. Damir Agičić održava nastavu od ak. godine 1996/1997. do 2000/2001. Godine 2000/2001. stalno zaposlenje na studiju povijesti nalaze diplomirani studenti prve generacije, danas doc. dr. sc. Marija Mogorović Crljenko i doc. dr.

Danas Zavod za povijesne i društvene znanosti HAZU.

Zapisnik sjednice Fakultetskog vijeća u Pismohrani Pedagoškog fakulteta u Puli.

U tom je razdoblju zamjenik bio izv. prof. dr. sc. Ivan Jurković. 
sc. Maurizio Levak. Sljedeće akademske godine kao vanjski suradnik pridružuje se dr. sc. Alojz Štoković, a stalno je zaposlen dr. sc. Igor Duda. Kao profesor latinskog jezika, poseban pečat studiju u njegovim prvim godinama davao je mr. sc. Jakov Jelinčić.

Uvođenjem studiranja po tzv. Bolonjskoj deklaraciji 2005., Filozofski fakultet u Puli, na temelju tada postojećih dvopredmetnih studija, uvodi nove jednopredmetne studijske grupe: Povijest i Hrvatski jezik i književnost. Glavna obilježja programa su izbornost i interdisciplinarnost. Student obveznim predmetima usvaja sva temeljna znanja iz svjetske i hrvatske povijesti, ali u znatnoj mjeri samostalno oblikuje svoj studij putem izbornih modula i predmeta. Sukladno Europskom sustavu prijenosa bodova (ECTS) student upisuje i kolegije koji se nude na drugim studijima, unutar i izvan matičnog odjela ili sveučilišta. Modulski dio studija postao je još atraktivniji angažiranjem više vanjskih suradnika: dr. sc. Mirela Altić, dr. sc. Mislava Bertoša, dr. sc. Sandi Blagonić, dr. sc. Lidija Nikočević i dr. Kenneth R. Valpey, a od akademske godine 2011/2012. i dr. sc. Raul Marsetič. Posljednjih godina, kao naslovna asistentica, pridružila se Iva Kolić.

Tri godine po pokretanju preddiplomskoga studija, akademske godine 2008/09. upisan je prvi naraštaj diplomskoga studija povijesti. Cilj trogodišnjega preddiplomskog studija povijesti (jednopredmetnog i dvopredmetnog) te dvogodišnjega diplomskog studija povijesti (jednopredmetnog i dvopredmetnog) osposobljavanje je studenata za istraživanje povijesti u skladu sa suvremenim historiografskim načelima te obrazovanje nastavnika za prenošenje znanja o povijesti na nove naraštaje. ${ }^{15}$

Osnivanjem Sveučilišta Jurja Dobrile u Puli, 21. prosinca 2006. ${ }^{16}$, Filozofski fakultet u Puli izdvaja se iz Sveučilišta u Rijeci i dijeli na tri sveučilišne sastavnice: Odjel za humanističke znanosti, Odjel za studij na talijanskom jeziku i Odjel za glazbu. Tada Odjel za humanističke znanosti "nasljeđuje“ dopusnice za jednopredmetni preddiplomski i diplomski studij Hrvatskoga jezika i književnosti, jednopredmetni preddiplomski i diplomski studij Povijesti, dvopredmetni preddiplomski i diplomski studij Talijanskog jezika i književnosti te dvopredmetni preddiplomski studij Latinskog jezika i rimske književnosti. Na dvopredmetnome preddiplomskome i diplomskome studiju moguće su sve kombinacije studija Povijesti, Hrvatskoga jezika i književnosti, Talijanskoga jezika i književnosti te Latinskoga jezika i rimske književnosti.

Odsjek za povijest od tada čine dvije katedre. ${ }^{17}$ Katedru za staru i srednjovjekovnu povijest, čiji je voditelj prof. dr. sc. Robert Matijašić, čine još prof. dr. sc. Klara BuršićMatijašić, izv. prof. dr. sc. Ivan Jurković, doc. dr. sc. Maurizio Levak, dr. sc. Robert Kurelić, viši asist. (znanstveni novak), Marina Zgrablić, asist., Davor Bulić, asist. (znanstveni novak) i Katarina Gerometta, asist. (znanstvena novakinja). Katedru za novovjekovnu i suvremenu povijest, čiji je voditelj prof. dr. sc. Slaven Bertoša, čine prof. dr. sc. Nevio Šetić, doc. dr. sc. Igor Duda, doc. dr. sc. Marija Mogorović Crljenko, dr. sc. Iva Milovan Delić, viša asist., dr. sc. Mihovil Dabo, viši asist. te dr. sc. Danijela Doblanović, viša asistentica.

Danas je Odsjek, možemo reći, dobrim dijelom ekipiran, a vanjska suradnja svedena je na samo nekoliko profesora koji nastavu svojih predmeta održavaju svake druge akademske godine. Dr. sc. Iva Milovan Delić zaposlena je 2006., a dr. sc. Mihovil Dabo i dr. sc. Robert Kurelić 2007. Naredne godine, 2008., kao znanstveni novaci zaposleni su Marina Zgrablić

15 Tekst doc. dr. sc. Igora Dude na internetskim stranicama Sveučilišta.

16 Sveučilište Jurja Dobrile u Puli osnovano je Zakonom o osnivanju Sveučilišta u Puli 29. rujna 2006., a upisano u Registar Trgovačkoga suda u Pazinu 21. prosinca 2006., stekavši time pravni status. (http://hr.wikipedia.org/ wiki/Sveu\%C4\%8Dili\%C5\%A1te_Jurja_Dobrile_u_Puli)

17 Na 3. sjednici, održanoj 6. lipnja 2007., pod točkom 3 utvrđeno je da se Odjel za humanističke znanosti sastoji od četiri odsjeka, a Odsjek za povijest čine dvije katedre. Predstojnica Katedre za staru i srednjovjekovnu povijest bila je tada doc. dr. sc. Klara Buršić-Matijašić. Na čelu Katedre za novovjekovnu i suvremenu povijest bio je prof. dr. sc. Miroslav Bertoša. 
i Davor Bulić, a 2009. dr. sc. Danijela Doblanović. Katarina Gerometta posljednja je u nizu zaposlenih mladih i perspektivnih snaga našeg Odsjeka.

U programu studija povijesti sudjeluju i nastavnici s drugih odsjeka Sveučilišta, bilo da se radi o predmetima povijesno-antropološke tematike (dr. sc. Andrea Matošević) ili pak predmetima vezanim uz latinski jezik (dr. sc. Ante Matan, dr. sc. Zvonimir Milanović, dr. sc. Gorana Stepanić) ili stranim jezicima za povjesničare (mr. sc. Davorin Brajković, Marijeta Djaković, prof., dr. sc. Igor Grbić, mr. sc. Ana Sekelj, Tarita Štokovac, prof.).

Djelatnici Odsjeka u sklopu Odjela, osim nastavnim bave se i znanstvenim radom, provode znanstveno-istraživačke projekte (nacionalne i međunarodne), objavljuju znanstvene i stručne radove ${ }^{18}$. Odjel organizira znanstvene skupove ${ }^{19}$, seminare, okrugle stolove i tribine, objavljuje znanstveni časopis Tabula (od 1999.) ${ }^{20}$, znanstvena djela, monografije $^{21}$ i udžbenike ${ }^{22}$ u sklopu izdavačke djelatnosti Sveučilišta ili u suizdavaštvu ${ }^{23}$. Pri Odsjeku od 2001. djeluje podružnica Međunarodne udruge studenata povijesti (ISHA) ${ }^{24}$

18 Vidi bibliografiju nastavnika na mrežnim stranicama: www.unipu.hr/index.php?id=povijest

19 Samostalno ili u suorganizaciji s drugim ustanovama.

Od 2003. godine u Poreču se održava „Istarski povijesni biennale“. Uz Sveučilište suorganizatori su Zavičajni muzej Poreštine - Museo del territorio parentino i Državni arhiv u Pazinu. U organizacijskom odboru skupa bili su profesori našeg Odsjeka: Miroslav Bertoša, Robert Matijašić, Marija Mogorović Crljenko.

Godine 2004. u suorganizaciji Instituta Ivo Pilar održan je znanstveni skup „Identitet Istre - ishodište i perspektive".

31. listopada 2007. u Svečanoj dvorani „Tone Peruško“ održan je Međunarodni znanstveni skup „150 godina od prvog modernog habsburškog popisa stanovništva“ koje je suorganiziralo Humanistično društvo Histria - Società umanistica Histria - Humanističko društvo Histria.

Od 30. svibnja do 2. lipnja 2012. u Puli je bio organiziran 15. Mediterranean Studies Association Congress. Predsjednik organizacijskog odbora bio je prof. dr. sc. Robert Matijašić.

20 U razdoblju od 1999. do 2004. kada je tiskano čak sedam brojeva, glavni urednik bio je prof. dr. sc. Robert Matijašić. Od ponovnog pokretanja tiskanja časopisa, 2010., glavna urednica je prof. dr. sc. Klara BuršićMatijašić.

21 Navodim samo neke. Opširnije na sveučilišnim stranicama Odsjeka (http://www.unipu.hr/index.php?id=415). Miroslav Bertoša, „Mletačka Istra u XVI. i XVII. stoljeću“. Knjiga druga. U: Društvene strukture, populacija i gospodarstvo, Istarska naklada, Biblioteka „Misao", Pula 1986., 520 str.

Robert Matijašić, „Gospodarstvo antičke Istre, arheološki ostaci kao izvori za poznavanje društvenogospodarskih odnosa u Istri u antici (I. st. pr. Kr. - III. st. posl. Kr.)“ (Riassunto: Storia economica dell'Istria antica; Zusammenfassung: Die Wirtschaftliche Istriens in der Antike; Summary: The Economic History of Istria in Antiquity), Povijest Istre, knjiga 4., ZN „Žakan Juri“, Pula 1998., 636 str.

Ivan Jurković, Medieval Narrative Sources. A Chronological Guide, Budimpešta: Charles Schlacks, Jr. for the Department of Medieval Studies CEU, 1999., xvi + 139 str. - koautori János M. Bak i Ryszard Grzesik.

Slaven Bertoša, Život i smrt u Puli. Starosjeditelji i doseljenici od XVII. do XIX. stoljeća, Skupština udruga Matice hrvatske Istarske županije, Pazin 2002.

Klara Buršić-Matijašić, „Gradine Istre. Povijest prije povijesti“, U: Povijest Istre VI., Zavičajna naknada „Žakan Juri", Pula 2007., 805 str.

Igor Duda, U potrazi za blagostanjem. O povijesti dokolice i potrošačkog društva u Hrvatskoj 1950-ih i 1960-ih, Srednja Europa, Zagreb, 2005.

Marija Mogorović Crljenko, Druga strana braka, Zagreb: Srednja Europa, 2012.

Nevio Šetić, Ostvarenje suvremene hrvatske države, Od pojave višestranačja 1989. do nastanka samostalne međunarodno priznate i teritorijalno cjelovite Republike Hrvatske, Pula 2013.

22 Robert Matijašić, Uvod u latinsku epigrafiju, Knjižnica Tabule, sv. 3, Pula 2002.; Slaven Bertoša, Svjetska povijest modernog doba (XVI.-XIX. stoljeće) s posebnim osvrtom na Apeninski poluotok, Zagreb 2004.; Klara BuršićMatijašić, Gradinska naselja, Gradine Istre u vremenu i prostoru, Leykam international, Zagreb 2008.

23 Odjel odnosno Odsjek odnosno Sveučilište pojavljuje se kao suizdavač zbornika iz serije Histria colloquium III „Prvi moderni popis stanovništva u Istri - II primo censimento demografico moderno in Istria - Prvi moderni popis prebivalstva v Istri“, ur. Aleksej Kalc, Koper Capodistria 2012., u čijem su uredniškom odboru prof. dr. sc. Robert Matijašić i dr. sc. Danijela Doblanović.

24 U Puli je od 5. do 11. travnja 2004. održana 15. međunarodna Konferencija studenata povijesti s glavnom temom „Trgovina i komunikacije“. Prijavilo se i sudjelovalo je preko 80 studenata iz svih krajeva Europe, a pored stručnog dijela prezentirana je i povijest našeg grada i države. 
koja objavljuje studentski časopis „Epulon“. Studenti Povijesti, osim što vrijedno izvršavaju svoje obaveze propisane studijskim programom, aktivni su i u raznim tijelima Sveučilišta, kao što i obilježavaju važne povijesne obljetnice. ${ }^{25}$

Odsjek je uspostavio uspješnu suradnju sa srodnim humanističkim visokim učilištima u zemlji i inozemstvu (Zagreb, Split), kao i razmjenu studenata i nastavnika putem raznih oblika programa Erasmus. Naši nastavnici održali su niz predavanja na drugim sveučilištima ${ }^{26}$, a mi smo ugostili kolege profesore ${ }^{27}$, čijim smo nastupima obogatili program pojedinih predmeta.

Danas Odsjek za povijest broji 15 članova, sedam u znanstveno-nastavnim zvanjima i osam u suradničkom zvanju asistenta ili višeg asistenta. Nastavnici su iskazivali svoje znanstvene interese putem nekoliko znanstvenih projekata: „Naseljenost i gospodarstvo Istre od kraja prapovijesti do Bizanta“, „Srednjovjekovna Istra: prostor zajedništva i suprotnosti (od VI. do XVI. st.)“, „Elitne i marginalne skupine u Istri od XVI. do XVIII. stoljeća“ te „Istarsko društvo XVI.-XIX. stoljeća: povijesne i kulturološke teme“. Nastavnici su također bili uključeni i u projekte čiji su nositelji bili znanstvenici s drugih sveučilišta ili znanstvenih ustanova.

Doc. dr. sc. Igor Duda jedan je od pokretača osnivanja Centra za kulturološka i povijesna istraživanja socijalizma koji je 2012. utemeljen kao nova sastavnica Sveučilišta Jurja Dobrile u Puli. Okuplja djelatnike raznih sveučilišnih odjela i umrežava znanstvenike koji dijele zanimanje za istraživanje razdoblja socijalizma i postsocijalizma te socijalističke i komunističke ideologije i teorije. U okviru centra zaposleni su naši bivši studenti, stručni suradnik Igor Stanić i vanjska suradnica Anita Buhin. ${ }^{28}$

Zahvaljujući nekim članovima Odsjeka, osnovano je 2010. Istarsko povijesno društvo - Società storica istriana sa sjedištem na našoj adresi. S ciljem promicanja i poticanja istraživanja istarske povijesti, pored više istarskih ustanova, u osnivanju Društva sudjelovao je Odsjek za povijest. U radu Društva naši nastavnici obnašaju vodeće uloge. Predsjednik Društva je doc. dr. sc. Maurizio Levak, a tajnica dr. sc. Danijela Doblanović. Glavni je projekt Istarskog povijesnog društva uređivanje i tiskanje historiografskoga časopisa Histria, čiji je suizdavač naše Sveučilište. Izdanje se bavi istarskim temama od najstarije povijesti do suvremenog doba, a pruža i godišnji pregled historiografskih događanja u Istri i o Istri. ${ }^{29}$

Iz redova nastavnika zaposlenih na Odsjeku za povijest valja istaknuti profesora Miroslava Bertošu, koji je među prvim na Sveučilištu stekao počasni naslov professor emeritus. ${ }^{30}$ Nadalje, Miroslav Bertoša obnašao je i dužnost generalnog konzula Republike Hrvatske.

25 Na Vijeću Odjela za humanističke znanosti, na 18. sjednici, 12. listopada 2009., izvješćeno je da će od 9. do 13. studenog na Sveučilištu, biti organiziran Kulturno-umjetnički festival KUFer. Bit će upriličena izložba povodom obilježavanja 20 godišnjice pada Berlinskog zida, razne radionice, književne večeri te koncerti.

26 Navodimo samo izbor gostujućih predavanja:

Prof. dr. sc. Slaven Bertoša gostovao je 17. siječnja 2013. na Odsjeku za povijest Filozofskog fakulteta u Zagrebu, održavši studentima II. godine diplomskog studija, na predmetu Habsburška Monarhija: imperijalna baština (nositelj doc. dr. sc. Hrvoje Petrić) predavanje: „Lupoglav i Lupoglavska gospoštija u srednjem i novom vijeku.“ Dr. sc. Robert Kurelić sudjelovao je, od 1.-12. srpnja 2013. na Ljetnoj školi META humanistika, Kopar: Univerza na Primorskem, s predavanjem „Princes, Captains and Peasants: Contested Space in Sixteenth Century Istria“. Dr. sc. Marija Mogorović Crljenko je 30. studenog 2012. na Filozofskom fakultetu u Zagrebu - u sklopu suradnje zagrebačkog i pulskog odsjeka za povijest, na kolegiju Rođaci i bližnji - obiteljske strukture (nositeljica dr. sc. Zrinka Nikolić, doc.), održala predavanje: „Sklapanje braka u istarskim komunalnim društvima.“

27 Navodimo samo izbor gostujućih predavanja:

U svibnju 2013. dr. sc. Andrej Rahten s mariborskog sveučilišta predstavio je svoju knjigu Jugoslavenska velika noč. Slovenski pogledi na balkanski vojni (1912-1913) in jugoslavensko prašanje, a dr. sc. Zrinka Blažević, sa Filozofskog fakulteta Sveučilišta u Zagrebu, održala je predavanje „Ranonovovjekovna orijentalna carstva Kina".

28 http://www.unipu.hr/index.php?id=1501\&L=2\%27\%60\%28\%5B\%7B, 21. ožujka 2014.

29 http://ipd-ssi.hr/?page_id=6, 21. ožujka 2014.

30 Njemu u čast tiskan je zbornik (u tri sveska) čiji je glavni urednik izv. prof. Ivan Jurković. 
Profesor dr. sc. Robert Matijašić obnašao je dužnost prodekana i dekana Filozofskog fakulteta, a potom prorektora i rektora Sveučilišta. Prorektor za znanost bio je i izv. prof. dr. sc. Ivan Jurković.

Nadalje, od 1990. prof. emerit. Miroslav Bertoša član je suradnik HAZU-a, dok je na Izbornoj skupštini održanoj 15. svibnja 2014. za člana suradnika izabran i prof. dr. sc. Robert Matijašić.

Naši su nastavnici angažirani na mnogim poljima i izvan Sveučilišta sudjelovanjem u raznim povjerenstvima gradskih, županijskih i državnih tijela.

\section{Ambiciozni planovi}

Odsjek za povijest Odjela za humanističke znanosti u Akcijskom planu Sveučilišta Jurja Dobrile u Puli za razdoblje 2013-2015. prijavio je nove sveučilišne programe. U pripremi je program poslijediplomskog doktorskog studija povijesti s kojim ćemo stvoriti pretpostavke za početak rada doktorskog studija i pokrenuti postupak akreditacije. U pripremi je realizacija dugogodišnje ideje o pokretanju Jadranske medijevističke radionice, na kojoj bi se mlade stručnjake uvodilo u posebnu metodologiju znanstvenog rada na arhivskoj građi. S obzirom na to da smo od samih početaka formiranja studija u neraskidivoj vezi s Odsjekom za kroatistiku našeg Sveučilišta, predviđeno je sudjelovanje u organizaciji ljetne škole hrvatskoga jezika. Naši će djelatnici povijesnim temama doprinijeti tečaju Ljetna škola hrvatskoga jezika, koji će omogućiti stranim studentima u razmjeni stjecanje kompetencija iz hrvatskoga jezika.

Odsjek, uz već dugogodišnju plodnu suradnju s Odsjekom za povijest Filozofskog fakulteta Sveučilišta u Zagrebu i Odsjekom za povijest Filozofskog fakulteta Sveučilišta u Splitu planira uspostaviti suradnju s Oddelkom za zgodovino FHV Univerze na Primorskem u Kopru. Suradnja se sastoji u razmjeni studenata i profesora između dvaju odsjeka, odnosno odlazak profesora na srodne odjele Sveučilišta i uzvratne posjete grupe studenata svake druge godine.

U narednom razdoblju planira se snaženje zapošljavanja sukladno mogućnostima.

Osim održavanja nastave i napredovanja nastavnika, razvoj našeg Odsjeka vidimo u osnivanju Centra za interdisciplinarna arheološka istraživanja, unutar kojega će se organizirati radionice, seminari, davati stručna mišljenja. Jedan od ciljeva bit će povezivanje prakse, znanosti i obrazovanja te suradnja s ustanovama u Hrvatskoj i inozemstvu koje se bave arheologijom i srodnim disciplinama.

Za još čvršće pozicioniranje Odsjeka za povijest kao centra izvrsnosti i modernih promišljanja te snaženje prepoznatljivosti na međunarodnom planu smišljeno je bienalno održavanje međunarodnog kongresa povjesničara „Past, Present, Future“. Već tradicionalno djelatnici našeg Odsjeka sudjeluju kao suorganizatori Istarskog povijesnog Biennala, čime će se nastaviti suradnja s Državnim arhivom u Pazinu i Zavičajnim muzejem Poreštine - Museo del Parentino, koja traje od 2003. Prožimanje nastavnog procesa i znanstvenih istraživanja vidimo i u nastavku suradnje s Centrom za kulturološka i povijesna istraživanja socijalizma koji okuplja suradnike i s našeg Odsjeka.

Odsjek čine zaposlenici, profesori, asistenti, znanstveni novaci, profesori u stalnom radnom odnosu, kao i oni gostujući, a njihovi osobni uspjesi su i uspjesi Odsjeka. Svima njima, sadašnjima i bivšima, hvala na trudu i zalaganju, jer bez njihovog doprinosa ne bismo "odgojili" toliki broj generacija studentica i studenata kojima smo pružili znanje, ali i ljubav prema struci. 


\section{POPIS LITERATURE}

\section{BENUSSI 1923}

Bernardo Benussi, Pola nelle sue istituzioni municipali dal 1797 al 1918, Parenzo 1923.

\section{BOGNERI 1989}

Marcello Bogneri, Cronache di Pola e dell'Istria: 1847-1914, Trieste: Unione degli Istriani, s.a. (ca. 1989.)

\section{DEMARIN 1978}

Mate Demarin, Hrvatsko školstvo u Istri: Pregled razvoja 1818-1918., Zagreb 1978.

\section{ĐILAS 2004}

Milica Đilas, „'Ville Münz' u Puli, urbanističkoarhitektonska cjelina s početka 20. st., Arhitektura i urbanizam", Zbornik I. kongresa hrvatskih povjesničara umjetnosti, Zagreb, 15. - 17. XI. 2001., ur. Milan Pelc, Zagreb 2004., 153-160.

\section{KRIZMANIĆ 2005}

Attilio Krizmanić, „Prostorni razvitak austrijske Pule", u: Pula, Tri tisućljeća mita i stvarnosti, Pula 2005., 113-192.

\section{MALVIĆ 2005}

Jasna Malvić, „Secesija“, Istarska enciklopedija, ur. M. Bertoša i R. Matijašić, Zagreb 2005., 719-720.

\section{MUNIĆ 2006}

Vesna Munić, „Akademik Petar Strčić kao utemeljitelj studija i sveučilišni profesor povijesti u Rijeci“, Časopis za povijest Zapadne Hrvatske, I./1., Rijeka, 2006., 129-133.

\section{PETRIĆ 1986}

Pavao Petrić, Nastavna djelatnost Pedagoške akademije (1961-1978), Nastavna djelatnost Pedagoškog fakulteta (1978-1986), Od Akademije do OOUR-a Nastavna djelatnost, u: Spomenica Pedagoške akademije / Pedagoškog fakulteta u Puli 1961-1986. - Memoriale dell'Accademia / Facoltà di pedagogia di Pola, Pula 1986., 10-17.

\section{UJČIĆ 1964}

Vitomir Ujčić, Pula, Zagreb 1964.

\section{SAŽETAK}

Studij povijesti prvi je put osnovan u Puli na tadašnjoj Pedagoškoj akademiji 1961., na kojoj se povijesna grupa predmeta u kombinaciji s drugim studijima održala do 1970. Nakon duže pauze, početkom 1990-ih pokrenuta je inicijativa za otvaranjem suvremenog programa studija povijesti, koji je nakon duge i zamršene procedure utemeljen 1994. na tadašnjem Pedagoškom fakultetu, a koji je 1998. preimenovan u Filozofski fakultet, a 2006. ušao je u sastav Sveučilišta Jurja Dobrile u Puli, kao odsjek Odjela za humanističke znanosti. Ustanova ima dopusnice za jednopredmetni i dvopredmetni preddiplomski i diplomski studij povijesti.

Glavna obilježja programa studija povijesti na Odsjeku za povijest jesu izbornost i interdisciplinarnost. Student obveznim predmetima usvaja temeljna znanja iz svjetske i hrvatske povijesti, ali u znatnoj mjeri samostalno oblikuje svoj studij putem izbornih modula i predmeta. Sukladno Europskom sustavu prijenosa bodova (ECTS), student upisuje i kolegije koji se nude na drugim studijima, unutar i izvan matičnog odjela. Prve godine upisano je 26 studenata, od kojih je njih 21 uspješno završilo studij.

Od početnih dvaju stalno zaposlenih profesora, i više vanjskih suradnika s drugih sveučilišta i drugih ustanova, danas je na Odsjeku za povijest zaposleno petnaest nastavnika, od toga osam u znanstveno-nastavnim zvanjima, i sedam u suradničkim zvanjima. Rad nastavnika na Odsjeku organiziran je u dvije katedre, Katedri za staru i srednjovjekovnu povijest i Katedri za novovjekovnu i suvremenu povijest. Djelatnici Odsjeka u sklopu Odjela, 
osim nastavnim bave se i znanstvenim radom, provode znanstveno-istraživačke projekte (nacionalne i međunarodne), objavljuju znanstvene i stručne radove u zemlji i inozemstvu. Mnogi su obnašali važne dužnosti unutar i izvan Sveučilišta (rektor, prorektor, generalni konzul RH), a iz redova nastavnika pojedinci se ističu u pokretanju i osnivanju Centra za kulturološka i povijesna istraživanja, kao i Istarskog povijesnog društva.

Odsjek u sklopu Odjela organizira znanstvene skupove, seminare, okrugle stolove i tribine, objavljuje i dijelom uređuje znanstveni časopis Tabula (od 1999.), znanstvena djela, monografije i udžbenike. Pri Odsjeku od 2001. djeluje podružnica Međunarodne udruge studenata povijesti (ISHA), koja objavljuje studentski časopis „Epulon“. Odsjek je uspostavio uspješnu suradnju sa srodnim humanističkim visokim učilištima u zemlji i inozemstvu, kao i razmjenu studenata i nastavnika putem raznih oblika EU-ovog programa Erasmus.

Nastavnici će u narednom razdoblju nastaviti raditi na pozicioniranju Odsjeka za povijest kao centra izvrsnosti i modernog historiografskog promišljanja, kako bi bili prepoznati na međunarodnom planu, suradnjom s drugim Sveučilištima i srodnim ustanovama, pokretanjem doktorskog studija, osnivanjem Centra za interdisciplinarna arheološka istraživanja, pokretanjem Jadranske medijevističke škole, sudjelovanjem u organizaciji i provođenju ljetnih škola te bienalnoj organizaciji kongresa povjesničara.

\section{SUMMARY}

\section{Twenty Years of the University Studies in History in Pula (1994 - 2014)}

The study of history in Pula was first established in the then Pedagogical Academy in 1961, where history was taught in combination with other curricula, but it was closed in 1970. After a long pause, in the early 1990s an initiative was launched for the establishing of a modern study of history, which was established in 1994 after long and complicated procedures, in the then Pedagogical Faculty, which was renamed Faculty of Philosophy in 1998 and has become part of the Juraj Dobrila University of Pula in 2006, as Department of Humanities. The institution has the license for single major and double major, undergraduate and graduate studies of history.

The main features of the study programme of the Sub-department of History are its interdisciplinarity and the possibility to choose single courses. The student adopts a basic knowledge of world and Croatian history in compulsory core subjects, but he independently shapes his study curriculum to a considerable extent through modules and courses of his own choice. In accordance with the European Credit Transfer System (ECTS) the student can also choose courses which are on offer in other study programmes within the Department and in other departments of the University. In 1994, 26 students enrolled in the first year, of whom 21 successfully completed the study.

The Sub-department of History started with two full-time teachers and several visiting teachers from other universities. Today the Sub-department employs 15 teachers, of whom 8 with academic titles and 7 assistants. The Sub-department has two chairs, one for ancient and medieval history, and the other for modern and contemporary history. Besides teaching, the members of the Sub-department are also active in scientific activities, projects (national and international), they publish scientific and other papers in Croatia and abroad. Some of them held important functions within and outside the University (Rector, Vice Rector, Consul General), while some from our ranks were among the founders of the Centre for cultural and historical research of socialism (CKPIS), and of the Istrian Historical Society (IPD-SSI). 
Within the Department, the Sub-department organizes conferences, seminars, round tables, lectures, it contributes to the editing of the Department's scientific journal "Tabula“ (since 1999), it produces scientific monographs and textbooks. Since 2001, a group of students of the Sub-department are organized into a local section of the International Students of History Association (ISHA), and they publish the students' journal "Epulon“. The Sub-department has established a successful cooperation with similar humanities departments at home and abroad, as well as the exchange of students and teachers through various forms of the EU Erasmus Programme.

In the future, the teaching staff will continue to work on the positioning of the Subdepartment as a centre of excellence and modern historical thinking, so as to be recognized in the international arena in collaboration with other universities and similar institutions, by establishing doctoral studies, the foundation of the Centre for Interdisciplinary Achaeological Research, an Adriatic Medievalist School, by participating in the organization of summer schools and a biennial history conference.

Keywords: history curriculum, Juraj Dobrila University of Pula, Department of Humanities, Sub-department of History 